\title{
Peningkatan Hasil Belajar Matematika Siswa SMA Negeri 1 Marisa Melalui Model Pembelajaran Kooperatif Tipe Team Games Tournament (TGT)
}

\author{
Selvi Tora \\ Guru SMA Negeri 1 Marisa
}

\author{
Received: 13 August 2021; Revised: 02 October 2021; Accepted: 14 December 2021 \\ DOI: http://dx.doi.org/10.37905/aksara.8.1.375-380.2022
}

\begin{abstract}
Abstrak
Penelitian ini bertujuan mengumpulkan dan menganalisis data tentang upaya meningkatkan hasil belajar matematika melalui model pembelajaran kooperatif tipe Team games tournament pada kelas XII IPA SMA Negeri 1 Marisa. Penelitian ini menggunakan penelitian tindakan kelas sebanyak dua siklus. Setiap siklus terdiri dari empat tahap, yaitu: rancangan, kegiatan dan pengamatan, refleksi, dan revisi. Subjek penelitian ini adalah siswa kelas XII IPA SMA Negeri 1 Marisa Tahun Pelajaran 2018/2019. Dari hasil analisis didapatkan bahwa hasil belajar siswa mengalami peningkatan dari pra siklus, siklus I sampai siklus II, yaitu pra siklus, siklus I $(68,42 \%)$, siklus II. Simpulan dari penelitian ini adalah model pembelajaran kooperatif tipe Team games tournament dapat berpengaruh positif terhadap hasil belajar peserta didik Kelas XII IPA SMA Negeri 1 Marisa, serta model pembelajaran ini dapat digunakan sebagai salah satu alternatif pembelajaran matematika.
\end{abstract}

Kata kunci: Hasil belajar, matematika, Team games tournament

\section{PENDAHULUAN}

Tujuan pembelajaran matematika di jenjang Pendidikan Menengah adalah untuk mempersiapkan peserta didik agar sanggup menghadapi perubahan keadaan di dalam kehidupan dan di dunia yang selalu berkembang melalui latihan bertindak atas dasar pemikiran secara logis, rasional, kritis, cermat, jujur, efisien, dan efektif. Di samping itu, peserta didik diharapkan dapat menggunakan matematika dan pola pikir matematika dalam kehidupan sehari- hari dan dalam mempelajari berbagai ilmu pengetahuan yang penekanannya pada penataan nalar dan pembentukan sikap peserta didik serta keterampilan dalam penerapan matematika.

Dalam proses pendidikan tidak lepas dengan proses pembelajaran, baik proses belajar peserta didik atau proses mengajar yang dilakukan pendidik. Agar proses belajar mengajar sesuai dengan tujuan yang diharapkan dibutuhkan fasilitas, kreativitas, media, metode maupun strategi yang tepat (keaktifan) sesuai dengan kapasitas peserta didik.(Hamzah;2011)

Di berbagai sekolah kita sudah menemukan penggunaan metode dan berbagai macam model pembelajaran. Tapi terkadang peserta didik merasa jengkel dengan metode yang ada karena mungkin tidak tepat dalam penggunaan metode pada materi pembelajaran. Tidak jarang muncul keluhan matematika cuma bikin pusing peserta didik bahkan dianggap sebagai momok yang menakutkan oleh sebagian siswa. Begitu beratnya gelar yang disandang oleh matematika yang membuat kekhawatiran pada prestasi belajar matematika siswa. Faktor lain yang juga ikut mempengaruhi rasa jengkel dan bosan pada matematika adalah tidak adanya hal yang dianggap menyenangkan dalam pembelajaran matematika seperti permainan dalam pembelajaran. Hal ini bisa berdampak pada keaktifan siswa dalam belajar matematika, misalnya tidak 
mau mengerjakan tugas, malas membaca, malas bertanya, malas meresume, bahkan malas mengikuti pelajaran. Tidak sedikit siswa yang berusaha menghindari mata pelajaran matematika. Hal ini jelas sangat berakibat buruk bagi perkembangan pendidikan matematika ke depan.

Hasil belajar siswa pada mata pelajaran matematika dengan KKM 75, dengan daya serap tuntas yang diharapkan $75 \%$, dari 38 siswa. Hanya 14 siswa yang memenuhi standar KKM dengan daya serap secara klasikal 37\%. Melihat kondisi ini dicoba menggunakan model pembelajaran kooperatif yaitu model pembelajaran kooperatif tipe Team games tournament (TGT). Diharapkan dengan model pembelajaran kooperatif tipe Team games tournament (TGT) ini dapat membuat siswa lebih termotivasi dan aktif dalam pembelajaran matematika dan pada akhirnya dapat meningkatkan hasil belajar mereka.

Pembelajaran kooperatif adalah sebuah kelompok strategi pengajaran yang melibatkan siswa bekerja secara berkolaborasi untuk mencapai tujuan bersama. Menurut Ibrahim (2000) belajar kooperatif dapat mengembangkan tingkah laku kooperatif dan hubungan yang lebih baik antar siswa dan dapat mengembangkan kemampuan akademis siswa. Menurut Bayor (Hidayanto, 2006) Team games tournament (TGT) adalah salah satu model pembelajaran aktif yang pelaksanaannya banyak melibatkan siswa. Model pembelajaran kooperatif tipe Team games tournament (TGT) adalah model pembelajaran yang diawali dengan membentuk kelompok. Siswa mendapat tugas dari guru untuk membuat pertanyaan yang dibentuk bola dan dilemparkan kepada siswa lain. Siswa yang menerima bola menjawab pertanyaan tersebut.

Menurut Sudjana (2009) hasil belajar adalah kemampuan-kemampuan yang dimiliki siswa setelah ia menerima pengalaman belajarnya yakni keterampilan dan kebiasaan, pengetahuan dan pengertian, sikap dan cita-cita. Kemampuan kognitif, afektif maupun psikomotorik dapat dikuasai dari proses belajar mengajar. Kunandar (2013) mengatakan bahwa hasil belajar adalah kompetensi atau kemampuan tertentu baik kognitif, afektif maupun psikomotorik yang dicapai atau dikuasai siswa setelah mengikuti proses belajar-mengajar.

Perubahan tingkah laku dapat berupa perubahan terhadap pengetahuan, sikap dan keterampilan. Disamping terjadinya perubahan tingkah laku, banyak hal lain yang didapatkan dari belajar tersebut diantaranya seseorang dapat memperoleh kecakapan, mendapatkan keterampilan dan menentukan suatu sikap. Namun semuanya itu bukanlah disebabkan oleh karena adanya proses kematangan. Menurut Purwanto (2011) hasil belajar dapat didefinisikan dan dapat dipahami dengan dua kata yang membentuknya yaitu "hasil" dan "belajar" pengertian hasil belajar menunjukkan pada suatu perolehan akibat dilakukannya suatu aktivitas atau suatu proses yang mengakibatkan berubahnya input secara fungsional. Penelitian ini bertujuan untuk meningkatkan hasil belajar matematika siswa melalui model pembelajaran kooperatif tipe Team games tournament (TGT) pada kelas XII IPA SMA Negeri 1 Marisa.

\section{METODE PENELITIAN}

Penelitian ini merupakan penelitian tindakan kelas (classroom action research), karena penelitian dilakukan untuk memecahkan masalah pembelajaran di kelas. Penelitian ini juga termasuk penelitian deskriptif, sebab menggambarkan bagaimana 
suatu teknik pembelajaran diterapkan dan bagaimana hasil yang diinginkan dapat dicapai.

Penelitian ini mengacu pada perbaikan pembelajaran yang berkesinambungan. Tahapan penelitian tindakan pada suatu siklus meliputi perencanaan, pelaksanaan, observasi, dan refleksi. Siklus ini berlanjut dan akan dihentikan jika sesuai dengan kebutuhan dan dianggap sudah cukup. Penelitian dilaksanakan di SMA Negeri 1 Marisa tahun pelajaran 2018/2019. Penelitian dilakukan di kelas XII IPA tempat dilaksanakannya pembelajaran matematika selama ini. Subjek penelitian sebanyak 38 siswa.

Penelitian dilaksanakan selama dua bulan yaitu Februari-Maret 2019 semester genap tahun pelajaran 2018/2019. Indikator keberhasilan penelitian ini dengan menggunakan hasil nilai pembelajaran KKM $75 \%$ dan telah terjadinya peningkatan hasil belajar siswa terhadap pelajaran Matematika. Penelitian ini dilakukan melalui tiga tahap, yaitu: (1) tahap persiapan, kegiatan yang dilakukan dalam tahap persiapan ini adalah mempersiapkan segala sesuatu yang berhubungan dengan pelaksanaan penelitian. Dalam kegiatan ini diharapkan pelaksanaan penelitian akan berjalan lancar dan mencapai tujuan yang diinginkan. Kegiatan persiapan ini meliputi: kajian pustaka, penyusunan rancangan penelitian, orientasi lapangan, dan penyusunan instrumen penelitian. (2) tahap pelaksanaan, pada tahap ini, kegiatan yang dilakukan meliputi: pengumpulan data melalui tes dan pengamatan yang dilakukan persiklus, diskusi dengan pengamat untuk memecahkan kekurangan dan kelemahan selama proses belajar mengajar persiklus, menganalisis data hasil penelitian persiklus, menafsirkan hasil analisis data, dan bersama-sama dengan pengamat menentukan langkah perbaikan untuk siklus berikutnya, dan (3) tahap penyelesaian yang meliputi: menyusun draf laporan penelitian, mengkonsultasikan draf laporan penelitian, merevisi draf laporan penelitian, menyusun naskah laporan penelitian, dan menggandakan laporan penelitian.

\section{HASIL PENELITIAN DAN PEMBAHASAN}

\section{Pra Siklus}

Kegiatan pada pra siklus, pembelajaran dilaksanakan dengan menggunakan metode ceramah yang diakhiri dengan pelaksanaan tes. Hasil proses pembelajaran terlihat monoton dan berpusat pada guru, sehingga dampak hasil belajar siswa rendah, dengan dibuktikan hasil tes. Ketuntasan belajar hanya mencapai 42,11\%. Pembelajaran yang dilakukan sebelumnya belum memberikan hasil yang maksimal.

\section{Siklus I}

Siklus pertama dilaksanakan dalam dua kali pertemuan atau dua kali tatap muka, dengan lama waktu 2 jam pelajaran yaitu 90 menit untuk satu kali pertemuan.

Berdasarkan analisis hasil tes dari 38 orang siswa diperoleh nilai rata-rata tes formatif 1 sebesar 74,08. Siswa yang telah mencapai atau memenuhi KKM sebanyak 26 orang dan yang belum memenuhi KKM sebanyak 12 orangDengan demikian, secara klasikal ketuntasan belajar yang telah tercapai sebesar 68,42\%. artinya secara klasikal termasuk belum tuntas atau belum berhasil. Hasil tersebut menunjukkan bahwa pada siklus pertama secara klasikal siswa belum tuntas belajar, karena siswa yang memperoleh nilai $\geq 75$ hanya sebesar $68,42 \%$ lebih kecil dari persentase ketuntasan yang dikehendaki yaitu sebesar $85 \%$. 
Jika diperhatikan, penyebabnya karena siswa masih belum siap membuat pertanyaan dan belum mampu menjawab pertanyaan dengan benar, apalagi materi transformasi geometri termasuk materi yang cukup sulit bagi mereka. Dari siklus pertama ini ditemukan beberapa kekurangan : 1) masih banyak siswa yang belum mampu dengan sigap mengikuti permainan, apalagi membuat pertanyaan, 2) masih banyak siswa yang merasa takut ketika menerima bola, karena takut tidak bisa menjawab, 3) masih banyak siswa yang hanya mengandalkan temannya untuk menjawab pertanyaan Dari kekurangan-kekurangan tersebut maka dilakukan perbaikanperbaikan dalam melaksanakan tindakan pada siklus selanjutnya seperti : 1) memotivasi dan membantu siswa agar mampu membuat pertanyaan, 2) memotivasi siswa untuk berusaha menjawab pertanyaan yang ditujukan padanya, 3) memotivasi siswa agar bertanggung jawab dengan tugasnya.

\section{Siklus II}

Siklus kedua dilaksanakan dalam tiga kali pertemuan atau tiga kali tatap muka, dengan lama waktu 2 jam pelajaran yaitu 90 menit untuk satu kali pertemuannya. Tindakan yang dilakukan pada siklus II berupa upaya pembenahan terhadap kekurangan pada siklus I.

Berdasarkan hasil tes formatif 2 dari 38 orang siswa diperoleh nilai rata-rata sebesar 80,78. Siswa yang telah mencapai atau memenuhi KKM sebanyak 33 orang dan yang belum memenuhi KKM sebanyak 5 orang. Maka secara klasikal ketuntasan belajar yang telah tercapai sebesar $86.84 \%$ atau dapat dikatakan secara klasikal, pembelajaran telah tuntas atau telah berhasil. Pada siklus ini ada peningkatan ketuntasan belajar secara klasikal dari siklus I dan II sebesar 13,04\%. Adanya peningkatan hasil belajar pada siklus II ini dipengaruhi oleh adanya peningkatan keinginan siswa dalam mempelajari dan menguasai materi pelajaran melalui model pembelajaran team games tournament (TGT) ini, disamping itu juga dipengaruhi oleh kemampuan guru dalam mengelola proses belajar-mengajar selama kegiatan pembelajaran berlangsung.

Kekurangan pada siklus I telah diperbaiki sehingga: 1) siswa sudah cukup mahir mengikuti permainan, dan juga mampu membuat pertanyaan, 2) siswa yang merasa takut ketika menerima bola, karena takut tidak bisa menjawab, sudah berkurang, 3) banyak siswa yang berusaha menjawab pertanyaan. Model pembelajaran kooperatif tipe team games tournament (TGT) memang baik diterapkan untuk mengaktifkan siswa, karena setiap siswa diminta untuk siap dalam menghadapi keadaan. Jika diminta menulis pertanyaan, maka setiap siswa mesti membuat pertanyaan. Jika bola kertas pertanyaan dilemparkan pada grup lain, maka seluruh anggota grup lain harus siap pula menjawab pertanyaan yang mungkin tertuju padanya. Dan pelemparan bola tersebut tidak hanya sekali, tapi berkali-kali sampai waktu belajar berakhir. Tentunya selama pembelajaran berlangsung, setiap siswa dalam kelompoknya berkemungkinan akan mendapat kesempatan. Dengan begitu, mau tidak mau setiap siswa harus belajar untuk menguasai materi yang diajarkan.

Andaikan siswa tidak mampu membuat pertanyaan ataupun menjawab pertanyaan secara mandiri, maka mereka dapat bertanya pada teman sekelompoknya, mereka dapat mendiskusikannya di dalam kelompoknya, dan mereka dapat memutuskannya bersama secara kelompok, walaupun nanti yang diminta menjawab hanya orang-perorang. Dengan demikian, hasil yang dicapai akan lebih baik. Guru dapat 
berperan juga membantu menghidupkan suasana belajar dalam permainan lempar bola, guru akan mengarahkan diskusi, membantu kesulitan siswa, dan sekaligus menyimpulkan hasil belajar.

\section{KESIMPULAN}

Dari hasil kegiatan pembelajaran yang telah dilakukan selama dua siklus, dan berdasarkan seluruh pembahasan serta analisis yang telah dilakukan dapat disimpulkan yaitu bahwa pembelajaran dengan model Team games tournament (TGT) memiliki dampak positif dalam meningkatkan hasil belajar siswa yang ditandai dengan peningkatan ketuntasan belajar siswa dalam setiap siklus, yaitu pra siklus $(42,11 \%)$, siklus I $(68,42 \%)$, dan siklus II $(86,84 \%)$.

Dari hasil penelitian yang diperoleh dari uraian sebelumnya agar proses belajar mengajar matematika lebih efektif dan lebih memberikan hasil yang optimal bagi siswa, maka disampaikan saran sebagai berikut: 1) Untuk melaksanakan belajar aktif memerlukan persiapan yang cukup matang, sehingga guru harus mampu menentukan atau memilih topik yang benar-benar bisa diterapkan dengan cara belajar aktif model pembelajaran kooperatif tipe team games tournament (TGT) sehingga diperoleh hasil maksimal. 2) Perlu adanya penelitian yang lebih lanjut, karena hasil penelitian ini hanya dilakukan di SMA Negeri 1 Marisa.

\section{DAFTAR PUSTAKA}

Hamalik, Oemar, 2007. Manajemen Pengembangan Kurikulum. Bandung: PT. Remaja Rosda Karya.

Hidayanto. 2006. Model-model Pembelajaran Efektif. Jakarta: PT. Bumi Aksara.

Ibrahim, Uslim. 2000. Pembelajaran Kooperatif. Surabaya: Surabaya University Press.

Kunandar. 2013. Langkah Mudah Penelitian Tindakan Kelas Sebagai Pengembangan Profesi Guru. Jakarta: PT. Raja Grafindo Persada.

Sagala, S. 2010. Konsep dan Makna Pembelajaran. Bandung: Alfabeta.

Sudjana, N. 2009. Penilaian Hasil Proses Belajar Mengajar. Bandung: Remaja Rosdakarya.

Suprijono, A. 2011. Cooperative Learning Teori dan Aplikasi PAIKEM. Yogyakarta: Pusaka Pelajar.

Undang-undang Sistem Pendidikan Nasional (UU Sisdiknas) No. 20 Tahun 2003. 
AKSARA: Jurnal Ilmu Pendidikan Nonformal

P-ISSN 2407-8018 E-ISSN 2721-7310 DOI prefix 10.37905

Volume 08, (1), January 2022

http://ejurnal.pps.ung.ac.id/index.php/Aksara 